\title{
KEWENANGAN MAJELIS PERMUSYAWARATAN RAKYAT MENURUT UNDANG- UNDANG NOMOR 2 TAHUN 2018 TENTANG MPR, DPR, DPRD, DAN DPD
}

\author{
Oleh: Poltak Siringoringo \\ Anton Silaban \\ poltaksiringoringo@gmail.com \\ Universitas Kristen Indonesia, Jakarta, Indonesia
}

\begin{abstract}
Indonesia has experienced rapid development in the state administration system since the demands for reform were marked by the fall of Soeharto from power in May 1998. Reformation as a form of total correction of the practice of running a centralized state that occurred during the leadership of the Orde Baru Era. The hegemony of the power of the President during the Orde Baru Era placed other state organs in a weak position functionally, including the Indonesian People's Representative Assembly. Since the Soeharto regime ended there was a fairly fundamental ow of change in the life of the Indonesian state administration. In the Indonesian constitutional structure, the People's Consultative Assembly of the Republic of Indonesiais one of the important pillars of the people's representative institutions besides the House of Representatives and the Regional Representative Council
\end{abstract}

Keywords:Orde Baru Era; Soeharto Regime; State Administration; Indonesian constitutional structure.

\section{Pendahuluan}

Sebelum amandemen UUD 1945, MPR adalah lembaga tertinggi negara dan pemegang amanat kedaulatan rakyat. Penempatan MPR sebagai pelaksana tertinggi kedaulatan rakyat Indonesia secara eksplisit diatur dalam Pasal 1 Ayat (2) UUD 1945 pra-amandemen. Majelis Permusyawaratan Rakyat Republik Indonesia berwenangmenetapkan UndangUndang Dasar dan Garis-Garis Besar Haluan Negara (GBHN). Pada sisi lain, MPR juga berwenang mengangkat dan memberhentikan Presiden dan Wakil Presiden, ini dikarenakan Presiden dan Wakil Presiden adalah mandataris MPR.

Pasca amandemen, terjadi penataan ulang terhadap bangunan sistem ketatanegaraan kita kearah yang lebih demokratis sesuai tuntutan reformasi. Organ MPR tidak lagi merupakan lembaga tertinggi negara dimana kedudukan disejajarkan dengan lembaga-lembaga negara lain yakni DPR, DPD, MA, dan sejumlah lembaga negara lain yang terbentuk setelah amandemen UUD 1945.
Hilangnya kewenangan MPR untuk memilih Presiden dan Wakil Presiden serta menetapkan Garis-Garis Besar Haluan Negara (GBHN) seolah menempatkan MPR sebagai lembaga darurat yang hanya akan bekerja jika terjadi usulan amandemen atas UUD, melantik Presiden dan Wakil Presiden, dan memilih Presiden dan Wakil Presiden jika terjadi kekosongan jabatan tersebut.

Adapun tugas dan wewenang MPR seperti berikut: (1) Mengubah dan menetapkan Undang-Undang Dasar Negara Republik Indonesia Tahun 1945; (2) Melantik Presiden dan/atau Wakil Presiden hasil pemilihan umum; (3) Memutuskan usul DPR untuk memberhentikan Presiden dan/atau Wakil Presiden dalam masa jabatannya, setelah Mahkamah Konstitusi memutuskan bahwa Presiden dan/atau Wakil Presiden terbuktimelakukan pelanggaran hukum berupa pengkhianatan terhadap negara,korupsi, penyuapan, tindak pidana berat lainnya, atau perbuatan tercela dan/ atau terbukti bahwa Presiden dan/atau Wakil Presiden tidak lagi memenuhi syarat sebagai Presiden dan/atau Wakil Presiden; (4) Melantik Wakil Presiden menjadi 
Presiden apabila Presiden mangkat, berhenti, diberhentikan, atau tidak dapat melakukan kewajibannya dalam masa jabatannya; (5) Memilih Wakil Presiden dari 2 (dua) calon yang diusulkan oleh Presiden apabila terjadi kekosongan jabatan Wakil Presiden dalam masa jabatannya; (6) Memilih Presiden dan Wakil Presiden apabila keduanya mangkat, berhenti, diberhentikan, atau tidak dapat melakukan kewajibannya dalam masa jabatannya secara bersamaandari 2 (dua) pasangan calon presiden dan wakil presiden yang diusulkan oleh partai politik atau gabungan partai politik yang pasangan calon presiden dan wakil presidennya meraih suara terbanyak pertama dan kedua dalam pemilihan umum sebelumnya, sampai berakhir masa jabatannya. Penghapusan kewenangan pembentukan TAP MPR ini didasarkan alasan untuk memperkuat sistem presidensial, dimana Presiden dan Wakil Presiden bukan lagi sebagai mandataris MPR dan tidak mempunyai garis pertanggungjawaban terhadap MPR dalam menjalankan kekuasaan pemerintahan.

Garis pertanggungjawaban Presiden dan Wakil Presiden sekarang langsung kepada rakyat berdasarkan ketentuan yang diatur dalam UUD 1945 pada Pasal 1 ayat 2 yang mengatakan "Kedaulatan berada di tangan rakyat dan dilaksanakan menurut UndangUndang Dasar".

Lebih lanjut di dalam perubahan UUD 1945 pada Pasal 24 C, dinyatakan pula bahwa "Mahkamah Konstitusi berwenang mengadili pada tingkat pertama dan terakhir yang putusannya bersifat finaluntukmenguji undang-undang terhadap Undang- Undang Dasar" ini berarti bahwa Mahkamah Konstitusi (MK) bertugas dalam rangka mengawal proses agar setiap hukum yang dibuat oleh Pemerintah tidak menyimpang dari konstitusi serta mengacu kepada Pancasila dan UUD 1945.

Berdasarkan uraian dalam latar belakang diatas maka dapat perumusan masalah penelitian ini adalah sebagai berikut:

1. Bagaimana pelaksanaan kewenangan konstitusional MPR dalam perspektif hukum tatanegara?

2. Bagaimana optimalisasi kewenangan MPR dalam perspektif hukum tatanegara?
Adapun tujuan penelitian untuk mengetahui dan menganalisakewenangan MPR dalam hukum tata Negara serta untuk mengetahui dan menganalisa apakah dengan optimalisasi kewenangan MPR sudah sesuai dengan hukum tata negara yang ada saat ini.

\section{Kedudukan MPR}

Istilah konstitusi pada umumnya menggambarkan keseluruhan sistem ketatanegaraan suatu Negara. Sistem itu berupa kumpulan peraturan yang membentuk, mengatur atau memerintah negara. Peraturanperaturan tersebut ada yang tertulis sebagai keputusan badan yang berwenang dan ada yang tidak tertulis yang berupa kebiasaan dalam praktik penyelenggaraan negara. Dengan demikian,pengertian konstitusi sampai dewasa ini dapat menunjuk pada peraturan ketatanegaraan baik yang tertulis maupun tidaktertulis.

Secara etimologi (bahasa), istilah "konstitusi" berasal dari bahasa latin "constitution atau constiuere" yang berarti "dasar susunan badan" dan menurut bahasa prancis disebut "constituer" yang berarti "membentuk". Pada zaman dahulu, istilah konstitusi dipergunakan untuk melaksanakan perintah Kaisar Romawi (yakni: constitutions principum). Kemudian di Iralia, konstitusi difungsikan sebagai UndangUndang Dasar (Diritton Constitutionale). Sedangkan makna konstitusi dalam bahasa Belanda disebut dengan "Grondwet".

\section{Konstitusi dan HukumDasar}

Konstitusi suatu negara pada dasarnya adalah konsep dasar dari sistem pengelolaan kehidupan bernegara. Bentuk konsep tersebut dapat sederhana atau lebih lengkap, dapat luas atau rinci sesuai kehendak masing-masing negara. Keadaan tersebut terlihat dengan adanya konstitusi yang pendek dankonstitusi yang panjang.

Konstitusi berfungsi sebagai hukum dasar yang memuat aturan-aturan dasar atau pokok-pokok penyelenggaraan negara yang masih bersifat umum atau bersifat garis besar dan perlu dijabarkan lebih lanjut ke dalam norma hukum di bawahnya. Di Indonesia, Pancasila merupakan dasar negara atau staat

\footnotetext{
1 Marwan Mas, Hukum Kostitusi dan Kelembagaan Negara, Raja
} grafindo Persada, 2018, Hal 11 
fundamental norm (norma fundamental negara) dan Undang-Undang Dasar Negara Republik Indonesia 1945 sebagai staats grundgesetz atau aturan dasar/ pokok negara ${ }^{2}$.

\section{Kewenangan MPR Sebelum Amandemen UUD1945}

Sebelum Amandemen UUD 1945, MPR didesain sebagai satu-satunya lembaga tertinggi negara dan pemegang utama kedaulatan rakyat Indonesia. Kedudukan MPR selaku pelaksana utama kedaulatan rakyat Indonesia secara jelas diatur dalam Pasal 1 Ayat (1) UUD 1945 pra- amandemen yakni Kedaulatan adalah ditangan rakyat dan dilakukan sepenuhnnya oleh Majelis Permusyawaratan Rakyat ${ }^{3}$

Sebelum amandemen UUD 1945, MPR hanya mempunyai tiga kewenangan konstitusional seperti ditegaskan dalam Pasal 3 dan Pasal 6 Ayat (2) UUD 1945 yakni:

- Menetapkan Undang-Undang Dasar.

- MenetapkanGaris-Garis Besar daripada Haluan Negara(GBHN).

- Memilih Presiden dan Wakil Presiden dengan suaraterbanyak.

Pilihan kewenangan menetapkan Undang-Undang Dasar yang diberikan kepada MPR oleh UUD 1945 sesungguhnya sudah cukup tepat. MPR merupakan lembaga yang merepresentasikan keterwakilan rakyat Indonesia. Menurut Pasal 2 Ayat (1) UUD 1945 pra amandemen, keanggotaan MPR terdiri atas anggota-anggota Dewan Perwakilan Rakyat ditambah dengan utusan-utusan dari daerah-daerah dan golongan- golongan, menurut aturan yang ditetapkan dengan undang-undang. Namun dalam UUD 1945 sendiri tidak ditemukan ketentuan dalarn Bab atau Pasal tertentu yang menjelaskan pengertian tentang keanggotaan MPR yang terdiri dari utusan-utusan dari daerah-daerah dan golongan-golongan tersebut. Kewenangan MPR untuk merumuskan dan menetapkan Garis-Garis Haluan Negara juga terkait dengan konstruksi UUD 1945 yang menempatkan Presiden sebagai mandataris MPR. MPR selaku lembaga negara

\footnotetext{
2 UUD 1945 dan Amandemennya untuk pelajar dan Umum, PT Grasindo, 2017, hal 29.

3 Lihat pasal 1 UUD 1945 Sebelum Diamandemen
}

tertinggi dalam sistem ketatanegaraan ini ditegaskan lebih jauh dalam bagian "Penjelasan UUD 1945 pra amandemen.Dikatakan bahwa, kekuasaan negara tertinggi ada di tangan MPR. Kedaulatan rakyat dipegang oleh badan bernama MPR sebagai penjelmaan seluruh rakyat Indonesia.

\section{Kewenangan MPR Setelah Amandemen UUD 1945}

Sesudah amandemen UUD 1945, terjadi perubahan struktur dan sistem ketatanegaraan yang sangat fundamental bagi kehidupan bangsa dan negara. Kedudukan MPR tidak lagi dikonstruksi sebagai lembaga tertinggi dan pelaksana utama kedauatan rakyat. Hakikat kedaulatan tetap berasal atau berada ditangan rakyat namun dalam implementasinya, harus berdasarkan atas prinsip-prinsip ketatanegaraan seperti diatur dalam Undang-Undang Dasar 1945.

Khusus terhadap eksistensi MPR, kedudukannya disejajarkan dengan lembaga negara lain seperti Dewan Perwakilan Rakyat, Presiden, Mahkamah Agung, Mahkamah Konstitusi, Dewan Perwakilan Daerah, Badan Pemeriksa Keuangan, Komisi Pemilihan Umum dan lain sebagainya.

MPR masih tetap berwenang menetapkan UndangUndang Dasar akan tetapi tidak lagi menetapkan GarisGaris Besar Haluan Negara (GBHN) dan memilih Presiden dan Wakil Presiden dengan suara terbanyak. Terjadi perubahan kewenangan MPR yang cukup siginifikan. Ketentuan Pasal 3 hasil amandemen ke Ill UUD 1945 mengatakan bahwa MPR mempunyai kewenangan konstitusional yakni:

- Mengubah dan menetapkan Undang-UndangDasar.

- Melantik Presiden dan/atau WakilPresiden.

- Hanya dapat memberhentikan Presiden dan/atau Wakil Presiden dalam masa jabatannya menurut Undang-UndangDasar.

Selanjutnya ketentuan dalam Pasal 3 diatas dijelaskan lebih jauh dalam Pasal 8 juncto Pasal 9 UUD 1945, dimana dikatakan bahwa MPR mempunyai kewenangan konstitusional untuk: ${ }^{4}$

- Mengubah dan menetapkan Undang-UndangDasar.

\footnotetext{
4 King Failsal Sulaiman dan Nenti Uji Apriliasari,op cit, $\mathrm{hlm}$
} 61 
- Memberhentikan Presiden dan/atau Wakil Presiden dalarn masa jabatannya menurut UndangUndangDasar.

- Memilih Presiden dan/atau Wakil Presiden untuk mengisi kekosongan dalam jabatan Presiden dan/ atau Wakil Presiden menurut Undang-UndangDasar.

- Mengadakan sidang MPR untuk pelantikan atau pengucapan sumpah/Janji jabatan Presiden dan/ atau Wakil Presiden.

Dibentuknya UU No. 2 Tahun 2018 tentang Perubahan kedua atas UU No. 14 Tahun 2014 Tentang MPR, DPR, DPD dan DPRD (MD3) kemudian menjelaskan lebih detail perihal kewenangan MPR yang dimaksud didalam kententuan Pasal 3 juncto Pasal 8 juncto Pasal 9 UUD 1945 pasca amandemen itu. Adapun ketentuan pada Pasal 4 UU No. 2 Tahun 2018 mengatakan bahwa MPR memiliki enam kewenangan konstitusional yakni.

1. Mengubah dan menetapkan Undang-Undang Dasar Negara Republik Indonesia Tahun1945.

2. Melantik Presiden dan/atau Wakil Presiden hasil pemilihanumum.

3. Memutuskan usul DPR untuk memberhentikan Presiden dan/atau Wakil Presiden dalam masa jabatannya, setelah Mahkamah Konstitusi memutuskan bahwa Presiden dan/atau Wakil Presiden terbukti melakukan pelanggaran hukum berupa pengkhianatan terhadap negara, korupsi, penyuapan, tindak pidana berat Iainnya, atau perbuatan tercela dan/atau terbukti bahwa Presiden dan/atau Wakil Presiden tidak lagi memenuhi syarat sebagai Presiden dan/atau Wakil Presiden.

4. Melantik Wakil Presiden menjadi Presiden apabila Presiden mangkat, berhenti, diberhentikan, atau tidak dapat melakukan kewajibannya dalam masajabatannya.

5. Memilih Wakil Presiden dari 2 (dua) calon yang diusulkan oleh Presiden apabila terjadi kekosongan jabatan Wakil Presiden dalam masajabatannya.

6. Memilih Presiden dan Wakil Presiden apabila keduanya mangkat, bcrhenti, dibcrhentikan, atau tidak dapat melakukan kewajibannya dalam masa jabatannya secara bersamaan, dari 2 (dua) pasangan calon presiden dan wakil presiden yang diusulkan oleh partai politik atau gabungan partai politik yang pasangan calon Presiden danWakilPresidennya meraih suara terbanyak pertama dan kedua dalam pemilihan umum sebelumnya, sampai berakhir masa jabatannya.

Kewenangan kontitusional untuk mengubah dan menetapkan Undang- Undang Dasar Negara Republik Indonesia Tahun 1945 tetap dipertahankan untuk dilekatkan kepada MPR selaku lembaga perwakilan rakyat. Perlu ditegaskan bahwa, komposisi keanggotaan MPR pasca amandemen UUD 1945 sudah berubah yakni terdiri dari anggota Dewan Perwakilan Rakyat dan anggota Dewan Perwakilan Daerah yang keduanya dipilih secara langsung melalui pemilihan umum setiap lima tahun sekali.

Setelah amandemen UUD 1945, Indonesia memiliki tambahan satu lagi lembaga perwakilan rakyat yakni Dewan Perwakilan Daerah (regional representation). Oleh karena itu, dapat dikatakan model lembaga parlemen Indonesia bersifat trikameralyang terdiri dari DPR, DPD, dan MPR. Pasal2 ayat (1) UUD 1945 menegaskan bahwa: Majelis Permusyawaratan Rakyat terdiri atas anggota Dewan Perwakilan Rakyat dan anggota Dewan Perwakilan Daerah yang dipilih melalui pemilihan umum dan diatur lebih lanjut dengan undang-undang.

Diawal era reformasi, Majelis Permusyawaratan Rakyat telah berhasil melakukan proses amandemen sebanyak empat kali terhadap UUD 1945 (1999-2002). MPR pada prinsipnya tidak berwenang lagi untuk memilih seorang Presiden dan Wakil Presiden dengan suara terbanyak seperti dalam praktek ketatanegaraan dizaman Orde Lama ataupun Orde Baru.Inidikarenakan, pasca amandemen mekanisme pemilihan Presiden dan Wakil Presiden harus melalui pemilihan umum yang dipilih secara langsung oleh rakyat.

Berdasarkan beberapa pengertian hukum tata negara melalui pendapat para ahli baik dari Indonesia maupun dari Eropa tersebut, terlihat ada perbedaan pendapat, tetapi di Sisi lain terdapat persamaan, sehingga pengertian hukum tata negara dapat dirangkai sebagai berikut: bahwa hukum tata negara adalah 
peraturan yang mengatur tentang penyelenggaraan pemerintahan yang diselenggarakan oleh pejabat- pejabat atau alat-alat perlengkapan negara/lembaga negara, sesuai dengan tugas dan kewenangannya masing- masing sebagaimana yang diamanatkan konstitusi negara negaranya, untuk mencapai cita-cita dan tujuan negara, sesuai dengan yang tercantum dalam konstitusi suatu negara yaitu kesejahteraan (Welfare state).

Setelah amandemen UUD 1945, tidak dikenal lagi adanya lembaga tertinggi negara. Kini doktrin pemisahan kekuasaan (separation of power) dalam arti modern yang bertumpu pada prinsip "checks and balances" antara cabang-cabang kekuasaan negara diterapkan dalamrangka membangun sistem ketatanegaraan yang lebih demokoratis. Baik MPR maupun DPR, DPD, Presiden/Wakil Presiden, Mahkamah Konstitusi, Mahkamah Agung, dan Badan Pemeriksa Keuangan, kesemuannya setara dan sejajar. Perubahan kedudukan MPR ini, ditegaskan lebih lanjut dalam UU No 2 Tahun 218 tentang Majelis Permusyawaratan Rakyat, Dewan Perwakilan Rakyat, Dewan Perwakilan Daerah, dan Dewan Perwakilan Rakyat Daerah (UU MD3) dalam pasal 3 yang berbunyi: "MPR merupakan lembaga permusyawaratan rakyat yang berkedudukan sebagai lembaga negara". UU MD3 Pasal 2 menyatakan Majelis Permusyawaratan Rakyat terdiri atas anggota Dewan Perwakilan Rakyat dan anggota Dewan Perwakilan Daerah yang dipilih melalui pemilihan umum.Penegasan Pasal 2 ayat diatas pada dasarnya mencerminkan bahwa lembaga MPR berdiri sendiri alias terpisah dari lembaga perwakilan rakyat yang lain yakni DPR dan DPD. Ketiga lembaga perwakilan rakyat itu juga mempunyai fungsi, dan kewenangan yang berbeda dan terpisah satu sama lain. Oleh sebab itu, kita dapat memahami Indonesia menganut sistem trikarneral (trikameralsystem), dimana MPR merupakan organ atau kamar ketiga dari struktur parlemen yang dipraktekkan di Indonesia. Ini berarti organ MPR bukanlah forum persidangan bersama "joint session" atau sidang gabungan seperti lazim diterapkan di negara-negara lain yang menganut sistem parlemen dua kamar (bikameralsystem).

Di lingkungan negara-negara yang menganut sistem parlemen dua kamar, memang dikenal adanya forum persidangan bersama di antara kedua kamar parlemen yang biasa disebut sebagai "joint session" atau sidang gabungan. Akan tetapi, sidang gabungan itu bukanlah lembaga yang tersendiri. Misalnya, di Amerika Serikat terdapat the House of Representatives dan Senate.Keduanya disebut sebagai Congress of the United States of America. Jika sidang gabungan atau 'joint session' diadakan, maka namanya adalah persidangan Kongres. Dalam Konstitusi Amerika Serikat disebutkan bahwa "All legislative power vested in Congress which consist ofthe Senate and the House of Representatives". Segala kekuasaan legislatif berada di Kongres yang terdiri atas House Representative danSenate.

Perlu diketahui bahwa setiap kewenangan yang dipunyai oleh tiap-tiap organ negara pada dasarnya bersumber pada dua jenis yakni kewenangan atributif dan delegatif. Kewenangan atributif dalam pembentukan peraturan perundang-undangan (attribute van wetgeving bevoegdheid) dapat diartikan sebagai bentuk pemberian atau penciptaan kewenangan membentuk peraturan perundang-undangan yang diberikan oleh UUD (grondwet) atau undang- undang (wet) kepada suatu lembaga negara atau lembaga pemerintahan. Atribusi bisa juga dimaknai sebagai wewenang yang melekat pada suatu jabatan. Atribusi ini menunjuk pada kewenangan asli atas dasar perintah konstitusi (UUD) atau suatu peraturan perundang-undangan yang berlaku.

Dalam perspektif MPR, kewenangan yang semula menetapkan Garis-Garis Besar Haluan Negara (GBHN) dan mengubah UIJD 1945 serta memilih Presiden dan Wakil Presiden terpilih setiap lima tahun ${ }^{5}$, kini diganti menjadi tiga kewenangan seperti diatur dalam ketentuan Pasal 3 UUD 1945. Bunyi pasal 3: (1)Majelis Permusyawaratan Rakyat berwenang mengubah dan menetapkan undang-undangdasar, (2) Majelis Permusyawaratan Rakyat melantik Presiden dan/atau Wakil Presiden, (3)Majelis Permusyawaratan Rakyat hanya dapat memberhentikan Presiden dan/ atau Wakil Presiden dalam masa jabatannya menurut undang-undang dasar.

Ada pula kewenangan MPR yang dijelaskan pada

\footnotetext{
5 Baca rumusan pasal 2 ayat (2) dan pasal 6 Ayat (2) sebelum amandemen ditegaskan bahwa"Presiden dan wakil presiden dipilih oleh MPR dengan suara yang terbanyak"
} 
bagian Pasal yang lain dalam UUD 1945. Ketentuan dalam Pasal 8 juncto Pasal 9 UUD 1945, juga menegaskan bahwa MPR mempunyai kewenangan untuk (1) mengubah danmenetapkan undang-undang dasar; (2) memberhentikan Presiden dan/atau Wakil Presiden dalam masa jabatannya menurut undang-undang dasar; (3) memilih Presiden dan/atau Wakil Presiden untuk mengisi kekosongan dalam jabatan Presiden dan/atau Wakil Presiden menurut Undang-Undang Dasar; dan (4) mengadakan sidang MPR untuk pelantikan atau pengucapan sumpah/janji jabatan Presiden dan/atau Wakil Presiden. Khusus dalam kasus pemakzulan (impeachment), organ MPR mempunyai kewenangan mutlak untuk memberhentikan Presiden dan/atau Wakil Presiden sebagaimana diatur dalam Pasal 7A UUD1945 yang berbunyi : Presiden dan/atau Wakil Presiden dapat diberhentikan dalam masa jabatannya oleh Majelis Pemusyawaratan Rakyat atas usul Dewan Perwakilan Rakyat, baik apabila terbukti telah rnelakukan pelanggaran hukum berupa pengkhianatan terhadap negara, korupsi, penyuapan. tindak pidana berat lainnya, atau perbuatan tercela maupun apabila terbukti tidak lagi memenuhi syarat sebagai Presiden dan/atau Wakil Presiden.

\section{Optimalisasi Kewenangan MPR didalam Perspektif Hukum TataNegara}

Tidak dapat dipungkiri bahwa yang mendirikan Negara Republik Indonesia adalah The Founding Fathers melalui anggota BPUPKI, kemudian digantikan menjadi PPKI, dan selanjutnya dikenal menjadi MPR. Lembaga tersebutadalahpemegangkekuasaannegaratertinggiataupemegangkedaulatan rakyat. Sebagai pemegang kekuasaan negara tertinggi, MPR membawahi lembaga-lembaga negara lain, terutama presiden, karena yang mengangkat dan memberhentikan presiden adalah MPR pada masa Orde Baru' ${ }^{6}$.

MPR Orde baru hasil Sidang Umum I (1966) di bawah demokrasi pancasila membuktikan bahwa anggota MPRS merasa dirinya berhak mengoreksi beberapa keputusan MPR sebelumnya. Hal ini mencerminkan tekad kuat menyelenggarakan accountability. Untuk itu beberapa keputusan orde lama, antara lain membatalkan TAP MPRS No.11//MPRS/1963 yang

\footnotetext{
6 Lintje anna marpaung, 2018, Hukum Tata Negara Indonesia, andi,hal 87
}

menyatakan Presiden Soekarno sebagai presiden seumur hidup. Selain itu, MPRS 'dalam rangka pemurnian pelaksanaan UUD 1945" menetapkan agar produk-produk legislatif di luar produk MPRS yang tidak sesuai dengan UUD ditinjau kembali (TAP MPRS No. XIX/MPRS/1996). Kekuasaan yang besar dari MPR dalam praktik ketatanegaraan, tidak jarang diselewengkan atau dipergunakan sebagai alat memperbesar kekuasaan presiden di luar ketentuan UUD 1945, seperti pemberian kekuasaan tidak terbatas kepada presiden melalui TAP MPR No. V/MPR/1998 tentang Pemberian Tugas dan Wewenang Khusus Kepada Presiden/Mandataris MPR RI Dalam Rangka Penyuksesan dan Pengamanan Pembangunan Nasional sebagai Pengalaman Pancasila.

Praktik-praktik yang melanggar UUD di atas, menyebabkan MPR dalam Sidang Tahunan 2001 memutuskan meniadakan Pasal 1 ayat (2) yakni "kedaulatan berada di tangan rakyat, dan dilakukan sepenuhnya oleh Majelis Permusyawaratan Rakyat" dan menggantinya menjadi "kedaulatan berada di tangan rakyat dan dilakukan menurut UUD". Perubahan itu mengisyaratkan bahwa kedudukan MPR tidak lagi sebagai lembaga tertinggi negara, dan tidak lagi memegang kedaulatan rakyat sebagaimana diatur dalam Pasal 1 ayat (2) UUD 1945. Perubahan tersebut juga berimplikasi pada pengurangan kewenangan MPR. MPR tidak lagi berwenang memilih presiden dan wakil presiden karena rakyat akan memilihnya secara langsung, wewenang MPR adalah melantik presiden dan wakil presiden hasil pemilihan rakyat. MPR pun tidak lagi berwenang memberhentikan presiden dan/ atau wakil presiden dalam masa jabatannya, tetapi kewenangan itu baru akan muncul ketika ada usulan dari DPR apabila ada mosi tidak percaya dari DPR, sesuai dengan tugas dan wewenang yang dimilikinya, yakni bertugas untuk mengawasi presiden.

Dalam hal memberhentikan presiden, UUD 1945 juga mengaitkannya dengan Mahkamah Konstitusi, sebagaimana yang diatur dalam Pasal 24C UUD1945, setelah Mahkamah Konstitusi memeriksa, mengadili, dan memutuskan bahwa presiden dan/atau wakil presiden bersalah kemudian Mahkamah Konstitusi menyerahkan hasil pemeriksaannya kepada DPR dan kemudian DPR menyampaikan hasil tersebut 
kepada MPR sebagaimana yang diatur dalam Pasal 7A, 7B UUD1945, bahwa MPR berhak memberhentikanpresiden walaupun MPR tidak lagi memilih dan mengangkat presiden.

Selanjutnya, akan dilihat susunan dan kedudukan MPR menurut Undang- undang Nomor 2 Tahun 2018 Tentang MD3 dan UUD 1945 untuk menentukan apakah merupakan sebuah lembaga permanen atau tidak. Status MPR jelas disebutkan berkedudukan sebagai lembaga negara. Anggota MPR terdiri atas anggota DPR dan DPD. Keanggotaan MPR diresmikan dengan Keputusan Presiden. Anggota MPR mengucapkan sumpah tersendiri yang terpisah dari sumpah anggota DPR atau DPD pada saat menjadi anggota DPR atau DPD. Anggota MPR juga memiliki Tata Tertib dan Kode Etik tersendiri serta memiliki hak-hak protokoler dan hakkeuangan ${ }^{7}$.

Berdasarkan pada ketentuan dalam susunan dan kedudukan MPR yang diuraikan tersebut, dapat disimpulkan bahwa MPR adalah sebuah lembaga permanen. Jika MPR adalah lembaga permanen, maka MPR merupakan kamar tersendiri dari parlemen dan sistem parlemen Indonesia adalah sistem parlemen trikameral. Dan dengan demikian sistem parlemen di Indonesia tidak dapat diklasifikasikan sebagai parlemen bikameral ${ }^{8}$.

Jimly Asshiddiqie walaupun pada awalnya mengusulkan pemikiran MPR hanya sebagai joint session, dan sebelumnya melihat bahwa keberadaan DPD adalah bentuk bikameralisme lunak, bahkan terlalu lunak, pada simposium Nasional Pembangunan Hukum Nasional di Bali menyatakan bahwa Parlemen Indonesia adalah Parlemen tiga kamar atau trikameral karena keberadaan MPR, DPR, dan DPD. MPR dipandang sebagai lembaga yang berdiri sendiridisamping DPR dan DPD. Hal ini berarti UUD 1945 memperkenalkan sistem baru yaitu trikameral atau trikameralisme.

Hal yang sama juga dikemukakan oleh Reni Dwi Purnomowati bahwa fungsi-fungsi MPR bukan meru- pakan fungsi yang rutin dan seandainya rutin hanya sekali dalam lima tahun. Karena itu adalah suatu yang berlebihan jika MPR dikatakan atau dijadikan sebuah lembaga. Pemikiran Dahlan Thaib dan Reni Dwi Purnomowati tersebut dengan sendirinya bertentangan dengan fakta hukum bahwa MPR adalah lembaga permanen berdasarkan ketentuan UUD 1945.

Maka untuk mengubah MPR dari sebagai lembaga permanen yang berdiri sendiri menjadi sidang gabungan, diperlukan pcrubahan-perubahan sebagai berikut:

Penegasan rumusan bahwa MPR adalah sidang gabungan antara DPR dan DPD. Rumusan juga dapat dibuat seperti pada konstitusi AmerikaSerikat,seperti diusulkan oleh Jimly Asshiddiqie sebagai berikut;"Kekuasaan legislatif dilakukan oleh Majelis Permusyawaratan Rakyat yang terdiri atas Dewan Perwakilan Rakyat dan Dewan Perwakilan Daerah".'

Anggota DPR dan DPD tidak disumpah lagi sebagai anggota MPR, sebab status keanggotaannya sebagai anggota DPR atau DPD secara otomatis pada saat sidang gabungan juga merupakan anggota MPR. Pimpinan sidang gabungan MPR tidak perlu dipilih tersendiri, tetapi dapat ditentukan Ketua DPR adalah Ketua MPR dan Ketua DPD adalah Wakil Ketua MPR, atau dapat dilakukan secara bergantian untuk kurun waktu tertentu, Anggota DPR dan anggota DPD tidak mendapatkan gaji atau pendapatan rutin lainnya sebagai anggota MPR. Namun masih dimungkinkan menerima uang sidang pada saat melakukan sidang gabungan yang dapat diatur dan diberikan oleh masing-masing sekretariat jenderal.

MPR dapat membentuk alat perlengkapan, seperti komisi, panitia ad hoc, atau Badan Pekerja, namun tidak bersifat permanen, hanya pada saat tertentu (misalnya pada saat mengadakan perubahan UUD) atau pada saat melakukan sidang gabungan, yang anggotanya merupakan gabungan antara beberapa anggota DPR dan DPD.
7 Muchammad Ali Safa'at, 2010, Parlemen Bimakeral, Universitas Brawijaya Press, hal 121

8 Asshiddqie, Struktur Ketatanegaraan Indonesia Setelah Perubahan Keempat UUD Tahun 1945.Makalah disampaikan dalam Simposium yang dilakukan oleh Badan Pembinaan hukum Nasional,Departemen Kehakiman dan HAM,2003, hlm 17

\footnotetext{
9 Asshiddiqie, Menuju Struktur Parlemen Dua Kamar,Makalah disampaiakan dalam seminar nasional tentang Bimakeralisme yang diselenggarakan oleh forum Rektor Indonesia bekerja sama denganNational Democratic Institute, Medan 12 Juni 2001,hal
} 4. 


\section{Kesimpulan dan Saran}

Kedudukan MPR berubah yang sebelumnya sebagai lembaga tertinggi negara menjadi lembaga tinggi negara yang sederajat, komposisi MPR pun berubah menjadi terdiri dari: anggota DPR dan ang- gota DPD, akibatnya kewenangan MPR dikurangi. MPR saat ini mempunyai kewenangan: (i) mengubah dan menetapkan UUD; (ii) melantik presiden dan/ atau wakil presiden; (iii) memberhentikan presiden dan/atau wakil presiden di tengah masa jabatan; dan

(iv) memilih presiden dan/atau wakil presiden dalam mengisi lowongan jabatan. (v) Memilih Wakil Presiden dari 2 (dua) calon yang diusulkan oleh Presiden apabila terjadi kekosongan jabatan Wakil Presiden dalam masa jabatannya; (vi) Memilih Presiden dan Wakil Presiden apabila keduanya mangkat, berhenti, diberhentikan, atau tidak dapat melakukan kewajibannya dalam masa jabatannya secara bersamaan, dari 2 (dua) pasangan calon presiden dan wakil presiden yang diusulkan oleh partai politik atau gabungan partai politik yang pasan- gan calon presiden dan wakil presidennya meraih suara terbanyak pertama dan kedua dalam pemilihan umum sebelumnya, sampai berakhir masajabatannya.

MPR tidak lagi menetapkan GBHN dan memi- lih presiden dan wakil presiden, akibatnya tidak satupun kewenangan MPR yang bersifat tetap.

Berdasarkan kesimpulan tersebut, penulis men- yarankan agar DPR merevisi UU tentang MD3, agar MPR hanya bersifat sementara saja karena tidak satu- punwewenang yang dimilikinya bersifattetap sehingga bisa menghemat anggaran negara. 


\section{Daftar Pustaka}

\section{Buku}

Marwan Mas, Hukum Kostitusi dan Kelembagaan Negara, Raja grafindo Persada, 2018.

UUD 1945 dan Amandemennya untuk pelajar dan Umum, PT Grasindo, 2017, hal 29.

Sulaiman, Faisal dan Nenti Uji Apriliasari, Menggugat Produk Hukum MPR RI Pasca Amandemen UUD 1945, UII Press, 2015.

Anna Mapaung, Lintje, Hukum Tata Negara Indone- sia, Edisi Revisi, Penerbit Andi Publisher (Andi Offset), 2018.

Muchammad Ali Safa'at, Parlemen Bimakeral, Uni- versitas Brawijaya Press, 2010.

Jimly Asshiddiqie, Pengantar Ilmu Hukum Tata Neg-ara, PT. Rajagrafindo Persada, Jakarta, 2011.

Jimly Asshiddiqie, PerihalUndang-Undang,Rajawali Pers, Jakarta, 2011.

\section{Peraturan Perundangan}

Undang-undang Dasar 1945 dan Amandemen, Pus- taka Sandro Jakarta, 2014

\section{Lain-lain}

Jimly Asshiddqie, Struktur Ketatanegaraan Indo- nesia Setelah Perubahan Keempat UUD Tahun 1945.Makalah disampaikan dalam Simposium yang dilakukan oleh Badan Pembinaan hu- kum Nasional,Departemen Kehakiman dan HAM,2003.

Jimly Asshiddiqie, Menuju Struktur Parlemen Dua Kamar,Makalah disampaiakan dalam seminar nasional tentang Bimakeralisme yang diseleng- garakan oleh forum Rektor Indonesia bekerja sama denganNational Democratic Institute, Medan 12 Juni 2001. 